\title{
Aspects Regarding Work-Life Balance of High- Skilled Employees in Some Romanian Services Sectors
}

\author{
Cristina Leovaridis and Elena-Mădălina Vătămănescu
}

National University of Political Studies and Public Administration, Bucharest, Romania

Correspondence should be addressed to: Cristina Leovaridis; cristina.leovaridis@comunicare.ro

Received date: 5 Septembre 2015; Accepted date: 19 December 2014; Published date: 31 August 2015

Copyright (C 2015. Cristina Leovaridis and Elena-Mădălina Vătămănescu. Distributed under Creative Commons CC-BY 4.0

\begin{abstract}
The present paper intends to achieve a comparison regarding work-life balance of high-skilled employees in five services sectors in Romania: advertising-marketing, IT\&C, financial-banking, research \& development, higher education. The research methodology is specific to a qualitative research, consisting of in-depth face-to-face interviews with high-skilled employees without managerial functions and managers of the above mentioned five sectors services. The paper begins with a literature review on a significant dimension of the employees' life quality, specifically the work-life balance, followed by a comparative statistical data analysis on the current situation of work-life balance in European countries. The results of the conducted field research showed that regarding work-life balance related to the necessity to provide some hours of one's free time in order to finish work duties, the best situation was found in IT\&C sector and R\&D sector (where none of the interviewees works in his free time and the employees' personal lives are not affected), followed by banking sector, where half of the interviewees work in their free time, in order to finish their tasks, then higher-education sector, where the majority claims to be working frequently after finishing teaching, in order to solve work tasks - preparing lectures, research or administrative activities, coordinating theses, which affects their personal life, and the advertising sector, with two-thirds of respondents stated that they work in their free time, after hours, which affects their personal lives.
\end{abstract}

Keywords: work-life balance, high-skilled employees, services sector.

\section{Introduction}

The concept of work-life balance (WLB) - a term coined in America, in 1986 (Lockwood, 2003, p. 2) - has been brought to the fore by the contemporary debate in the most developed Western countries. The issue entailed a special attention from academics, practitioners, businesses, government agencies, trade unions, media and the public opinion (Harris \& Foster, 2008, p. 1). The interest for the work-life balance became topical in the early nineties along with the escalation of work demands on employees and with the alteration of contemporary employment which afflicted the leisure sphere (White et al., 2003, pp. 223-235; MacInees, 2006, pp. 176-177). As a

Cite this Article as: Cristina Leovaridis and Elena-Mădălina Vătămănescu (2015), "Aspects Regarding WorkLife Balance of High-Skilled Employees in Some Romanian Services Sectors", Journal of Eastern Europe Research in Business \& Economics, Vol. 2015 (2015), Article ID 969136, DOI: 10.5171/2015.969136 
consequence, a wide body of literature was elaborated and exploited both constructively and critically on purpose to consolidate the work-life balance debate. Singh (2013, p. 84) posits that the issue of work-life balance has grown in popularity as it stood for a crucial driver for societal prosperity and fulfillment and growth of every worker and every company. This is why the main themes addressed have enhanced the relationship between the work-life balance and the quality of life conditions like career growth, job satisfaction, work appreciation and competitiveness, work stress and individuals' and organizations' initiatives and policies.

It is widely accepted that work-life policies evolved from family-friendly initiatives (White et al., 2003; Harris \& Foster, 2008). Still, over time, an extended work-life balance concept was developed focusing on the equilibrium between one's private life and work, for all workers independent of family status (Hyman et al., 2003, pp. 228230). Work-life balance is a much broader concept in comparison to work-family balance as it gathers a myriad of roles outside family life - leisure, friend and community networks, religious roles etc. (Frone, 2003, p. 144; Gregory \& Milner, 2009, pp. 1-2). The delineating line between the two concepts is still permissive as both of them are seen as self-reports of someone's understanding and as a perspective of balance between two roles. In other words, work-life balance is a multi-dimensional notion whose hard core is formed by the work-family balance and of other areas of life beyond family, as well (Jones et al., 2006, pp. 1-2; Shah, 2014, p. 12).

Thus, the term 'work-life balance' is preferred because it comprises the experiences and needs of both parents and non-parents and it establishes a reliable prerequisite for a more compelling theoretical framework (Redmond, Valiulis \& Drew, 2006, p. 18). In fact, the concept encompasses a satisfactory perspective on living and working, on "adjusting work patterns so that everyone, regardless of age, race or gender can find a rhythm that enables them more easily to combine work and their other responsibilities and aspirations" (Pilinger, 2001, p. 1). This approach is consistent with Drew and Daverth's (2009, pp. 24-25) view that a personal contentment is relevant for work performance and also that personal satisfaction stands for an accruing professional fulfillment.

Beginning from a broad theoretical documentation on an essential dimension of the employees' working conditions, specifically work-life balance, followed by a comparative statistical analysis on the situation of work-life balance in European countries, this paper aims to achieve a comparison regarding the work-life balance of employees in five services areas in Romania (advertising-marketing, IT\&C, financial-banking, research \& development, higher education), as shown in a qualitative research we conducted using semistructured interview guides, applied to some employees without managerial functions and managers of the five sectors services listed above.

\section{A Theoretical Approach Regarding Work- Life Balance}

An in-depth literature review on work-life balance brought to the fore nine major dimensions which should be taken into account when discussing the importance and prominence of the concept from a theoretical point of view. The nine categories which were created for a proper analysis of worklife balance fields of interest are: work-family conflict, individual-related variables, familyrelated variables, work-related variables, family and work-related variables, outcomes of work-family conflict, individuals' strategies for work-life balance, organizations' strategies for work-life balance and organizations' initiatives and programs for work-life balance.

The first dimension - work-family conflict triggered the attention of varied researchers, starting with Frone (2003), Hsieh et al. (2005), Baral \& Bhargava (2010), all of them focusing on different settings and identifying 
multiple directions of spillovers. For example, Hsieh et al. (2005, pp. 80-81) noticed that personal life has a limited effect on work in the case of Taiwanese managers. Additionally, Kinnunen and Mauno (2007, p. $175)$ concluded that the impact of work on the family is stronger than the opposite relation, irrespective of the respondents' genders. Hereby, Burke (2002, pp. 5-6) came to the conclusion that the preference for working in work-life balance-supportive organizations is applicable both for women and men.

Analyzing the interdependence of work and life in organizational settlements, Gibson (2006) advanced two possible explanations. Firstly, employees are prone to seek fulfillment on another level in order to compensate for personal or professional dissatisfaction and, secondly, individuals tend to let job satisfaction overflow into their work or family lives. A work-life imbalance is often correlated with tensions, stress, job dissatisfaction, anxiety (Aziz \& Cunningham, 2008, pp. 553-554; Baral \& Bhargava, 2010, pp. 297-298). On the contrary, a wellbalanced integration of personal and professional life is seen as both a private and organizational purpose which catalyzes the employees' effectiveness (Hyman \& Summers, 2007; Buddeberg - Fischer et al., 2008).

The study of individual-related variables has been undertaken by a high number of researchers who focused their attention on variables like age, gender, emotional intelligence, motivation, marital status etc. (Hyman et al., 2003; Hsieh et al., 2005; Grzywacz et al., 2007, 2008; Sjoberg, 2008; Gregory \& Milner, 2012). Investigating the role of marital status in the work-life balance framework, Hsieh et al. (2005, pp. 79-81) have not found significant differences neither between genders nor between married and unmarried managers. Next, Grzywacz et al. (2007, pp. 1127-1128) extended their studies to the cultural influence on the worklife conflict, the latter underlining that the more collectivist a culture is, the fewer conflicts appear between work and family. In the same theoretical framework, Sjoberg (2008, pp. 180-181) reported that high emotional intelligence is linked to a better equilibrium of life and work. As far as motivation is concerned, researchers have argued that the masculinity-femininity dimension is a reliable antecedent of motivation (Gregory \& Milner, 2011, 2012).

The family-related variables including couples' employment status, reciprocal support, parental/home responsibilities, number of children or spouse work hours have been addressed by researchers from the work-life standpoint (Guest, 2002; Frye \& Breaugh, 2004; Pedersen et al., 2011; Shah, 2014). The premises of these analyses reside in the dynamics of the work-cultures and structural and demographic shifts in the family within the Western industrial societies. At this level, Frye and Breaugh (2004, p. 197) posit that there is a positive relation between having a child care responsibility and a work-life balance. Moreover, Pedersen et al. (2011, pp. 307311) discriminated between dual-earners and single families with dependent children, stressing that different types of families may have a different concept on the work-life balance, findings that support largely Guest's (2002) rationale.

The examination of work-related variables within the work-life balance theory approaches issues like work schedule flexibility, task variety, autonomy and complexity, the number of worked hours (Hyman et al., 2007; Mayo et al., 2008; Macky \& Boxall, 2008; Steiber, 2009; Vanishree, 2012; Nordenmark, Vinberg \& Strandh, 2012). Mayo et al. (2008) and Macky and Boxall (2008) pointed out that working longer hours is linked to a greater work-life imbalance and that the power to act autonomously is positively correlated with work-life balance. Further, Steiber (2009, pp. 84-85) underlined that long working hours and the necessity of working overtime positively correlates with the escalation of the work-life conflict in general, and with work-family conflict in particular. Approaching the issue of self-employment, 
Nordenmark, Vinberg \& Strandh (2012, p. 2) argued that "psychosocial working conditions are important because demands and control in work influence work-life balance and well-being among self-employed men and women".

The family and work-related variables were subject of the theoretical and empirical examinations of Frye and Breaugh (2004), Kinnunen and Mauno (2007), Grzywacz et al. (2007), Tymon et al. (2011), Gupta and Sethi (2012). For example, Grzywacz et al. (2007, p. 1128) identified that gender is an important moderating factor of the level and antecedents of the work-life conflict that is, greater physical workload was correlated with a higher level of conflict in women's case, while greater psychological demands were more linked to work-family conflict in men's case.

A special attention was attributed to the relationship between career growth and work-life (family) conflict. Ballout (2008, pp. 460-461) emphasized that it is more likely for individual specific variables to predict a family-work conflict and perceived career success; at the same time, it is more likely for the work specific variables to predict workfamily conflict and career success. As far as job satisfaction is concerned, well-balanced work-life demands are very much associated with workers' physical and psychological health and performance, job satisfaction, turnover intentions (occupational variables).

The outcomes of work-life conflict were approached by Jones, Kinman and Payne (2006), Gambles, Lewis and Rapoport (2006), Jones, Burke and Westman (2006), Haris and Foster (2008), Haar and Bardoel (2008), Bagger et al. (2008), Livingston (2014), Young, Schieman and Milkie (2014). One major theme addressed by Jones, Kinman and Payne (2006, pp. 211-212) was the issue of quality of life as a cogent factor in relation to work-life balance. The extant literature flows with examples of negative influence of long working hours on employees, families, groups, communities and even workplaces. The physical and mental well-being is at stake whenever fatigue or exhaustion becomes viral within the work-eat-sleep cycle. Also, the health problems range from high blood pressure and heart problems to alcoholism, from lapses in concentration to risk-taking behaviors, from high levels of stress to the inability to manage complex situations (Jones, Kinman \& Payne, 2006).

Research findings indicate moderately to radically negative situations which afflict the general life satisfaction and reduce the employees' possibilities to spend qualitative time with family and friends, leading to the decay of the interaction and communication networks (Gambles, Lewis \& Rapoport, 2006). Moreover, authors point out that the inability of spending time with family members involves a strong feeling of loss and guilt and the undermining of traditional family values, namely time, love and care (Jones, Burke \& Westman, 2006, pp. 34-35). The negative outcomes reported at the workplace refer to the lack of productivity, accidents, absenteeism, job stress, depression, overall work strain, leaving and turnover, job dissatisfaction etc. (Haar \& Bardoel, 2008, p. 275).

Individuals' and organizations' strategies within the work-life balance framework have been approached by a myriad of researchers who address different types of strategies advanced by managers with a view to preserve the work-life balance: accommodating family terms, accommodating the organization commitments, negotiating with the family and staggering tasks (Guest, 2002; Hyman et al., 2003; Gambles, Lewis \& Rapoport, 2006; Powell \& Greenhaus, 2006; Singh, 2013). In this respect, Powell and Greenhaus (2006, pp. 1179-1180) found that employees resort to multiple cues when deciding the best way to manage potential work-life conflicts.

As far as the organizations' strategies are concerned, a wide spectrum of measures is considered to undermine the employees' work-life balance. Among these strategies, there should be mentioned the increased 
work intensity (as a consequence of restructuring or downsizing), the variation of the working hours in an unpredictable manner, structural or functional change as a result of technological developments (Gambels, Lewis \& Rapoport, 2006; Harris \& Foster, 2008; Thomas, 2014). In Hyman et al.'s (2005, p. 717) opinion, this situation was triggered by the outburst of the service sector accompanied by the liberalization of many economies that potentiated the demands for extended service periods.

Both employees and employers should assume proper strategies in order to balance work and non-work priorities so that workers perform job and family roles successfully. Organizations are liable to develop the pertinent infrastructure for supportive programs with a view to stimulating their employees' satisfaction successful family relationships and successful careers. Paille et al. (2010, p. 51) consider that a supportive attitude towards employees may be embodied in a clear proof of appreciation and a consistent preoccupation for their well-being. In this respect, De Cieri et al. (2005, p. 92) insist that organizations are prone to recruit and retain highly-skilled staff on purpose to survive and evolve on a competitive labor market. This exigency catalyzes the organizational awareness and action in view to implement and manage effective work-life strategies.

Dunne (2007, pp. 28-31) admits that recruiting and retaining well-trained and high-quality workforce is a twenty-first century great challenge for all organizational types and sizes. The imperative is to develop a strategic approach to attract, select, develop and retain highly-skilled prospects and the only way to achieve this objective is to deliver an appropriate answer to their societal needs. At this point, multiple studies have pointed out that workforce turnover should be seen as a consequence of the cleavage between management and employees (Curson \& Skidmore, 2010; Dawley, Andrews \& Bucklew, 2010).
An insight into the organizations' initiatives and programs for work-life balance reveals that researchers have consistently tried to examine the reasons for creating, developing and implementing them, the benefits of the employees and employers due to their practical application and the barriers in the programs implementation (Guest, 2002; Hyman \& Summers, 2004; Cieri et al., 2005; MacInnes, 2006; Parker, 2007; Dyne et al., 2009; Baral \& Bargava, 2011; Stepanova, 2012; Ong \& Jeyaraj, 2014).

As a response to theoretical and empirical studies, to the practitioners' claims and to media highlights, organizations have started introducing several programs to accrue the work-life balance for their employees. Among other initiatives, De Cieri et al. (2005, p. 92) and Parker (2007, p. 12) underline the importance of part-time jobs, working from home (part-time or full-time), job sharing, term-time working, shift working, study leave, zero hours contracts, flexitime and family matters leave. All these working time policies are meant to set up a balance between domestic commitments and employment which is beneficial to both individuals and organizations (Redmond, Valiulis \& Drew, 2006, p. 18).

Bloom et al. (2007, pp. 1-2) argued that work-life balance policies can stimulate productivity and contribute to a healthier workplace and the more competitive and globalized a firm is, the more it encourages the introduction of work-life policies with a view to enhance the effectiveness and performance of the organization. Moreover, Callan (2008, pp. 78-79) posits in his studies that resorting to flexible policies in organizations prevents the negative outcomes of work stressors on family satisfaction.

According to MacInnes (2006) and Jones, Burke and Westman (2006), the necessity for work-life balance initiatives in developed societies is triggered by the contemporary work mutations. Specifically, Harris and Foster (2008, pp. 2-4) mention three major issues which should be accounted for in this 
context: the increasing demands on employees, the rise of consumerism and the power of money which strengthen the prominence of paid work in individuals' life and the negative impact of overwork on life quality at both personal and professional levels. Furthermore, different research findings supported the idea that work-life balance initiatives underpin stress management, work motivation and loyalty to the organization, improved performance and higher professional commitment (Maxwell \& McDougall, 2004; Dyne et al., 2009).

The approach of work-life balance from a business standpoint was highlighted by Yasbek (2004) who considers that organizations should weigh up "the costs and benefits of introducing work-life balance policies" and determine "if the net impact is positive" (p. 2). In other words, from the organization's view, the initiatives and programs associated with the work-life balance are liable to be assessed in terms of profitability, financial performance and effective resource management. Accordingly, Ong and Jeyaraj (2014) noticed that that the effectiveness of work-life initiatives should conform to the main business strategy of today's organizations and that is imperative "to find credible ways to measure how these interventions affect key business strategies in organizations" (p. 8).

\section{A Statistical Overview on Work-Life Balance Situation In EU-27 Countries}

The issue of work and private life reconciliation has been intensively discussed on the European Union agenda, a welldefined balance between the two spheres being indicative of the quality of work and employment. The Europe 2020 Strategy is one main formal endeavor which refers to gender equality and to the imperative of stimulating employment participation of men and women. In this respect, the statistical data available in the Eurofound (2012b, pp. 8997) has shown several main results regarding the work-life balance among EU-27 Member States. Hereby, $18 \%$ of workers state to have inconveniences with balancing work and life, men being more affected than women - almost a quarter of 35-49 year-old men report cleavages between their working hours and their family and social activities (p. 90). Further, the findings indicate that long working hours have a bad effect on work-life balance; this is also the case for the alternation or shifts rotation and of work schedule changes. For example, only $14 \%$ of employees who have not experienced consistent schedule changes have reported work-life imbalance (p. 92). In order to preserve a good work-life fit, the study posits that having part-time jobs exerts a positive effect on the reconciliation between the professional and personal commitments, while working during spare time afflicts the employees' equilibrium. For example, only $13 \%$ of workers who value their leisure report having work-life imbalance compared with $27 \%$ of employees who do not delineate between free and work time (p. 94).

In what concerns telework and telecommuting, Eurofound (2012b, p. 95) reports that a quarter of the European workers are e-nomads, the percentages ranging from just above 5\% (in Romania, Bulgaria, Albania, Turkey) to over $40 \%$ (in Finland, Denmark, Sweden, Netherlands). These employees are majorly present in several activity sectors, as financial services, other services, education, public administration etc., while the highest incidence of e-nomads is seen in management positions and in professionals, technicians and associate professionals occupations.

The data made available by Eurofound (2012a, pp. 60-63) indicate that $22 \%$ of employees reported dissatisfaction regarding their work-life balance, the imperative for more flexible schedules being one common theme (p. 60). The difficulties in establishing a good equilibrium between work and family are pointed out by country and by working hours. Thus, 53\% of the European employees stated that they "have come from work too tired to do some of the household jobs which need to be done" (with the highest percentages in Cyprus 75\%, Greece 73\% and 
Latvia $70 \%$ ), $30 \%$ of them confirmed that "it has been difficult for them to fulfill their family responsibilities because of the amount of time they spend on the job" (with the highest percentages in Latvia $56 \%$, followed by Cyprus $52 \%$, Greece $48 \%$, Poland $45 \%$ and Spain $41 \%$ ) and only $14 \%$ of them said that "they have found it difficult to concentrate at work because of their family responsibilities". The data for Romania for these three items were, in order: $61 \%, 38 \%$ and respectively 16\% (Eurofound, 2012a, p. 61). According to average weekly working hours, $65 \%$ of European men and $72 \%$ of European women who work over 48 hours per week stated that they are "too tired to do household jobs", compared to $56 \%$ of men and $71 \%$ of women who work $41-47$ hours per week. In the same time, $46 \%$ of men and $51 \%$ of women who work over 48 hours per week answered that "it is difficult for them to fulfill family responsibilities", compared to $32 \%$ of men and $37 \%$ of women who work 41-47 hours per week (Eurofound, 2012a, p. 62).

From a bird's eye view, women report more problems than men in what concerns the work-life balance even though the number of working hours is the same. Regarding working hours and working arrangements, comparatively between men and women, Eurostat data show that $23 \%$ of all women employees in the EU usually work on Saturdays as compared with just under 21\% of men (Eurostat, 2008, p. 85). Still, as shown, men are the ones who work more per week, a fact that potentiates their perception of difficult reconciliation between personal and professional priorities.

These findings are consistent with the data provided by Eurostat (2009, pp. 48-49) which argue that the more hours a person works, the greater the difficulty in finding a good fit between work, family and other social activities. Due to the volume of working hours per week and to the way men organize their work, men employees report a higher level of dissatisfaction than women regarding their work-life balance. Also, the differences between genders from the part- time work standpoint are liable to account for their different levels of satisfaction with the work-life fit (p. 49).

As a conclusion, the issue of reconciling work, family and the social life keeps its topicality and pertinence on the European Commission agenda, with a focus on moderating gender and social groups inequalities (European Commission, 2014, pp. 29-31). Moreover, the correlations made between the Member States help the corresponding European institutions to develop consistent strategies and policies meant to underpin educational and employment systems and to cement a healthier private and work environment.

\section{Work-Life Balance In Services Sector In Romania}

\section{Research methodology}

The empirical research of this paper is part of a larger survey, which intended to study in detail the work conditions of Romanian highskilled employees in five sectors of services: marketing-advertising, IT\&C, banking, research \& development and highereducation. The complex initial research intended to collect data from employees and managers, regarding the following dimensions (Leovaridis, 2013, pp. 190-199, pp. 312-370): employees health problems related to the workplace, working time, work-life balance, work complexity and intensity, professional development possibilities, workplace autonomy levels and work organization, decision-making and leadership styles within the team and within the organization, organizational climate, culture and communication, motivational means and other processes of human resource management, social dialogue, measures suggested by employees and measures taken by employers in order to improve working conditions etc.

Based on this ample initial research, the present paper shall focus only on work-life balance item; the interview-guide questions regarding this dimension were: How often do 
you work in your spare time so that you can accomplish your work duties?; How is your working time planned (is it stable, established by the company without the possibility to change it/ I can adapt my working time within certain limits, flexible/ working hours are entirely decided by you)?; How often does it happen to not be able to fulfill your family/social commitments outside work because of it?; Is it difficult to get 1-2 free hours free from work in order to solve a personal/family matter?; Can you plan your holiday whenever you want to?.

The surveyed group was composed of 10-15 highly-qualified employees without any leadership positions and 2-3 managers, of each of the five sectors. We conducted a qualitative research, made up of face-to-face interviews with employees without any leadership positions, but also with employees with leadership positions from the above five services sectors. We have chosen different types of organizations, from the points of view of the sources of economic capital (state and private, Romanian and multinational), company dimensions (small, medium, large) and specialization, in order to build an overall image of the respective economic sector. At the end of quotations from the interviewees, employees from the advertising-marketing sector shall be abbreviated as A.E., IT\&C employees as IT.E., those of the banking sector as B.E, those of the research-development sector as R.E. and those of the higher education - E.E.; advertising managers - A.M., IT\& C managers - IT.M., banking and financial managers B.M, research-development managers as R.M. and the higher education managers - E.M.

\section{Research results}

Advertising-marketing sector. As far as the work-life balance is concerned, regarding the need to use some of one's spare time in order to finish on some work-related issues, twothirds of the responding employees stated that they work in their spare time, after working hours (in the evenings or during week-ends) in order to finish their tasks: "It is common to get home (usually late) and write something more in my work agenda, pretty much every evening. I also write on my phone in the metro or in the tram, so that I don't forget my ideas. Generally, I keep the briefs in my mind at all times and work on it even though that is not my intention" (A.E.4, 24 years old, multinational copywriter); "I've been through experiences such as having too much to work on, working outside the working time, giving up my personal life some years ago. Then, after nervous breakdowns and serious health problems, I realized that my life was worth more than anything" (A.E.11, 34 years old, social media coordinator); "Since the workload was large and there was no wellestablished working time (only the office arrival time was clear and needed to be respected), I couldn't perceive anymore a clear separation between my personal time and my work-related time" (A.E.14, 23 years old, multinational junior copywriter).

Half of the respondents claimed to be having a flexible working time ("within certain limits") and can take a few hours off their working time in order to solve a personal matter ("you're free to come and go whenever, as long as you don't miss the deadline" - A.E.4, 24 years old, multinational copywriter). The rest have a fixed working time, but the management accepts the taking of 1-2 hours off at a certain point in time, provided they are added to the working time later ("We agreed on the working time, so that it comprises 9 office hours. If I am looking forward to a few hours off in a certain day, I will make a written request and specify when exactly are those hours going to be made up for"- A.E. 8, 23 years old, Online Marketing Specialist).

There are, however, moments, when employees cannot solve a personal matter due to their workload (as stated by a quarter of the responding employees): "Sometimes I postpone or cancel going out because of work; it happens around twice a month" - A.E.3, 23 years old, senior account executive; "it happens at least once in a few days not to be able to participate in events or meetings which I would need for my personal and even 
professional development" - A.E. 8, 23 years old, Online Marketing Specialist.

As far as holidays are concerned, employees are free to take it whenever they wish to, but after handing in a notice in advance and discussing with the manager about those colleagues who are to replace them for the respective time frames etc.; there is also an exception, when "it was either an important client or project", and they could be asked to postpone their holidays.

IT\&C sector. Unlike the advertising sector, the majority of the respondents claim not to be working in their spare time or after working time (evenings or in the week-ends), in order to accomplish their tasks, as they enjoy a fixed schedule (generally consisting of 9 hours and 1 hour lunch break) during which they fulfill all their responsibilities so that their personal life is not affected: "I never work in my spare time. I can adapt my working time between certain limits. It was never the case not to be able to fulfill my family commitments because of the workplace" - IT.E.11, 26 years old, programmer; "I don't work in my spare time, but if I feel the need to develop professionally, I occasionally read at home. For the moment, my working time is fixed" - IT.E.7, 28 years old, programmer.

Some of the interviewees have a flexible working time, which means that they can arrive at work 1-2 hours sooner or later, but they have to stay for the mandatory 8 hours, or they can change shifts, but the number of working hours remains constant: "I don't work in my spare time (with the exception of the situation when I stay over hours). The working time is a fixed one, but there is a certain flexibility (normally, the working time is between 10-19, with a one hour break; there are co-workers who arrive at 9 o'clock, or even after 10, but as long as they work 8 hours and fulfil their tasks, nobody comments upon)" IT.E.3, 34 years old, programmer.

Of the 15 interviewed employees, only two stated that they spent more hours at work, after work: "I don't work at home (because I can't take with me all the software programs I have at work), so I spend extra time at the office to finish my tasks, pretty often, either at my own initiative, or after explicitly being told so. I no longer meet with my friends so often as before; because of my work, I only go out with them during the week-end" (IT.E.1, 24 years old, junior programmer); "Based on the project complexity, I stay over hours between 0 to 4 times a week" (IT.E.5, 31 years old, system engineer).

As far as the possibility of taking 1-2 free hours one day, the management agrees to it in general, but sometimes only provided these hours shall be made up for: "Yes, we are allowed to leave for 1-2 hours in order to solve personal matters, but we need to recover those hours" (IT.E.1, 24 years old, junior programmer).

In all cases, employees are free to take their holidays when they desire, but in certain conditions: depending on the project deadline, giving an advance notification (at least a month before), discussing about those colleagues who are likely to replace them during the specific time etc.: "One can go on holiday whenever he/she wants to, provided there is at least a month-advance discussion, in case of longer holidays" (IT.E.3, 34 years old, programmer); " Holidays depend on work load and project deadline” (IT.E.5, 31 years old, system engineer).

Financial-banking sector. Half of the respondents without a leadership position claim not to be working in their spare time or after work (in the evening or at week-ends) in order to finish their tasks, as they have a fixed working time, during which they can accomplish all their responsibilities, so that their personal life remains un-affected: "I don't work in my spare time. The working time is a fixed one, established by the company. I was never in the position to not be able to fulfill my family or social commitments because of work" - B.E.2, 36 years old, human resources project coordinator.

The remaining half, although having a fixed working time, often work in their spare time, 
in order to finish all their tasks or to study different documents, leaving their personal issues to be solved on week-ends only: "In our spare time, one needs to read regulations and product sheets etc." - B.E.4, 27 years old, account administrator; "Many times I stay over the working hours to finish my tasks. The working time is fixed, as it was established by the mother-company, without any possibility to change it. My work takes much of my time, so I would have to leave personal matters to be solved during the week-end" - B.E.8, 44 years old, customer counselor.

As far as the possibility of taking 1-2 hours free to solve personal matters is concerned, the management agrees to that in most cases, sometimes provided that those hours are made up for later: "In general, if I have a family matter I can take some time off, but I will have to make up for it; after all it is also in my best interest to stay 1 hour after working hours or catch up for some time off in order to achieve my target" (B.E.9, 25 years old, customer counselor); only two of those interviewed are exceptions, as it is impossible for them to take 1-2 free hours: "It is very difficult to take some time off during the working time, as the unit has a too small number of employees" - B.E.8, 44 years old, customer client.

In all cases, employees can have their holidays whenever they want, provided they respect several conditions: the holiday should not be at the same time as the deadline of delivery for a project, by announcing one's intentions to go on holiday at least three weeks in advance and only when there are colleagues who can "take over" temporarily, the holiday should not be scheduled at the same time with other colleagues' holidays etc.: "In general, I can take a holiday whenever I want to (it is important that it doesn't overlap with the debut or delivery deadlines of projects)" (B.E.2, 36 years old, human resources project coordinator); "Generally, yes, regarding the holiday, I have to discuss it with my colleagues, so that we don't overlap" (B.E.5, 26 years old, bank products coordinator).
Research-development. Although the majority of respondents claims to be working during the spare time, some of them only "sometimes", others "frequently", they all stated they have never been in the situation to neglect family commitments because of work, due to the fact that their working time is either flexible (in most cases), or fixed but "could be adapted to a certain extent": "I rarely work in my spare time; the working time is flexible and adaptable; I've always been able to fulfill my family and social commitments" (R.E.4, 32 years old, 3rd degree scientific researcher); "I frequently work at home after my job hours; I can adapt my schedule within certain limits; I was never in the situation to not be able to attend my social or family commitments on account of work" (R.E.9, 75 years old, 1st degree scientific researcher).

As far as the possibility to take 1-2 hours free at some point in time is concerned, absolutely all respondents claim not to be experiencing any difficulty in this regard. Also, in all cases, the employees can take their holidays whenever they feel like.

Higher education. From the point of view of the work-life balance with regard to the need to provide some of the spare time in order to finish work-related matters, there are several sector characteristics which have become visible, resulting from the statements made by the majority of respondents having no leadership positions: the lectures' schedule is fixed, but otherwise, the schedule is flexible; they frequently use their spare time in order to solve work-related matters connected with their research and administrative activities, preparing lectures and seminars, coordinating BA or MA theses etc., which transforms tasks into obstacles in fulfilling family or social commitments; cannot have spare hours during the lecture hours; can only plan their holidays during student holidays, respectively during the month of August and on Christmas.

The following paragraphs shall present several relevant opinions drawn from the above mentioned ideas: "I cannot take spare 
hours during the schedule and I can plan my holidays only when students are on the summer or winter holidays"- E.E.2, 31 years old, teaching assistant; "The work schedule is flexible with the exception of the teaching hours. For research one often uses his/her spare time. You cannot go on holiday except for school holidays" (E.E.10, 49 years old, associate professor); "I spend most of my spare time working. I can adapt my work schedule up to a certain extent. I can go on holiday only when my students go as well, and I generally have nothing to say about the respective period of time" (E.E.9, 34 years old, lecturer).

\section{Conclusions}

Focusing on the work-life balance related to the necessity to provide some hours of one's spare time in order to finish work issues, in the advertising sector, two-thirds of respondents claim that they work in their spare time, after hours (at evenings or in the week-end) in order to finish their tasks, which affects their personal lives; a situation leading to employee discontent is present as well in the higher-education sector, where the majority claims to be working frequently after finishing teaching, in order to solve work tasks - preparing lectures, research or administrative activities, coordinating theses, which affects their personal life; also, in the banking sector, half of the interviewees work in their spare time, in the evenings, at home, in order to finish their tasks or to read different documents, leaving their personal lives to be enjoyed during the week-end.

The best situation in this regard is in the IT\&C sector, where none of the interviewees works in his spare time and the employees' personal lives are not affected. The same is valid for the RD sector, where some claim to be working at home after hours but this does not affect their personal lives as they have a flexible schedule which could be adapted "to some extent", meaning that they attend the institute daily for 4 to 6 hours/day or they go there only on specific days.
In all five sectors, the management accepts it when employees require 1-2 hours off at a certain moment with a view to solve personal matters, provided these hours are made up for. Holidays can be scheduled whenever employees decide, provided they announce their intentions earlier and discuss them with colleagues so that they are replaced within this time frame etc.; the sole exception is offered by the situation when an important project has a short deadline, so that they might be asked to postpone their holidays. Another important exception is obvious in the case of higher education, when one can plan his/her holidays only during student summer holidays (in August) or for Christmas.

All in all, the profile of work-life balance among different services sectors has an intricate nature, as field specificity acts as a discriminating criterion. Work-related patterns and variables account for finding a good fit between personal and professional commitments and for the reconciliation of work and home so that both roles are fulfilled successfully. Along with working conditions, the individual-related variables should be given the due importance as they stand for reliable catalysts of underpinning a consistent equilibrium between multiple and varying responsibilities.

\section{References}

1. Aziz, S. and Cunningham J., (2008). Workaholism, work stress, work-life imbalance: exploring gender's role. Gender in Management: An International Journal, 23(8), 553-566.

2. Bagger, J., Li, A. and Gutek, B.A. (2008). How much do you value your family and does it matter? The joint effects of family identity salience, family-interface with work and gender. Human Relations, 61(2), 187-211.

3. Ballout, H.I. (2008). Work-family conflict and career success: the effects of domainspecific determinants. Journal of Management Development, 27(5), 437-466. 
4. Baral, R. and Bhargava, S. (2010). Workfamily enrichment as a mediator between organisational interventions for work-life balance and job outcomes. Journal of Managerial Psychology, 25(3), 274-300.

5. Bloom, N., Kretschmer, T. and van Reenen, J. (2006). Work life balance, management practices and productivity. [Online], [Retrieved September 15, 2014], http://cep.lse.ac.uk/conference_papers/Cam bridge2006/Bloom.pdf.

6. Buddeberg-Fischer, B., Stamm, M. and Klaghofer, R. (2008). The new generation of family physicians- career motivation, life goals and work-life balance. Swiss Med Wkly, 138(21-22), 305-312.

7. Burke, R. J. (2002). Organizational values, job experiences and satisfaction among managerial and professional women and men: Advantage men?. Women in Management Review, 17(5), 5-6.

8. Callan, S.J. (2008). Cultural revitalisation: The importance of acknowledging the values of an organisation's -golden erall when promoting work-life balance. Qualitative Research in Organisations and Management: An International Journal, 3(1), 78-97.

9. Curson, J. and Skidmore, T. (2010). Retaining a high quality workforce silver. Strategic HR Review, 9(5), 17-23.

10. Dawley, D.D., Andrews, M.C. and Bucklew, N.S. (2010). Enhancing the ties that bind: Mentoring as a moderator. Career Development International, 15, 259 - 278.

11. De Cieri, H., Holmes, B., Abbott, J. and Pettit, T. (2005). Achievements and challenges for work/life balance strategies in Australian organizations. The International Journal of Human Resource Management, 16(1), 90-103.

12. Drew, E. and Daverth, G. (2009). Living to Work.....Or Working to Live? The Role of Managers in Creating Work-Life Balance in Ireland. ICTU Briefing Paper. [Online]. [Retrieved August 12, 2014],
http://www.academia.edu/1436963/LIVING _TO_WORK....._OR_WORKING_TO_LIVE_THE_ ROLE_OF_MANAGERS_IN_CREATING_WORKLIFE_BALANCE_IN_IRELAND.

13. Drew, E., Humphreys, P.C. and Murphy, C. (2003) Off the Treadmill: Achieving Work-Life Balance: National Framework Committee for Family Friendly Policies. Dublin.

14. Dunne, H., (2007). Putting balance into business: Work/life balance as a business strategy for avoiding brain drain. Strategy $H R$ Review, 6(6), 28-31.

15. Dyne, L.V., Kossek, E. and Lobel, S. (2009). Less needs to be there: cross level effects of work practices that support work life flexibility and enhance group processes and group level OCB. Human Relations, 60(8), 1123-1154.

16. Eurofound (2012a). Third European Quality of Life Survey - Quality of life in Europe: Impacts of the crisis. Luxembourg: Publications Office of the European Union.

17. Eurofound (2012b). Fifth European Working Conditions Survey. Luxembourg: Publications Office of the European Union.

18. European Commission (2014). Gender equality in the workforce: Reconciling work, private and family life in Europe. Prepared for the European Commission Directorate General for Justice and Fundamental Rights. RAND Europe.

19. Eurostat (2009). Reconciliation between work, private and family life in the European Union. Luxembourg: Office for Official Publications of the European Communities.

20. Eurostat (2008). The life of women and men in Europe. A statistical portrait. Luxembourg: Office for Official Publications of the European Communities.

21. Frone, M.R. (2003). Work-family balance. In J. Quick, \& L. Tetrick (Eds.), Handbook of occupational health psychology (pp. 143- 
162). Washington, DC: American Psychological Association.

22. Frye, N.K. and Breaugh, J.A. (2004). Family-friendly policies, supervisor support, work- family conflict, family-work conflict, and satisfaction: A test of a conceptual model. Journal of Business and Psychology, 19, 197220.

23. Gambles, R., Lewis, S. and Rapoport, R. (2006). The myth of work-life balance: The challenge of our time for men, women and societies. West Sussex, England: John Wiley \& Sons.

24. Gibson, J. et al. (2006). Organizations: Behavior, Structure, Processes. New York: McGraw-Hill.

25. Gregory, A. and Milner, S. (2009). Editorial: work-life balance: a matter of choice?. Gender, Work \& Organization, 16(1), $1-13$.

26. Gregory, A. and Milner, S. (2012). Supporting fathers at work?. Paper for inaugural conference, International WorkFamily Research Network, New York, 14-16 June 2012.

27. Grzywacz, J.G., Arcury, T.A., Marin, A., Carrillo, L., Burke, B., Coates, M.L. and Quandt, S.A. (2007). Work-family conflict: Experiences and health implications among immigrant Latinos. J. Appl. Psychol, 92(4), 1119-1130.

28. Grzywacz, J.G., Quandt, S.A. and Arcury, T.A. (2012). Immigrant Farmworkers' Health-Related Quality of Life: An Application of the Job Demands-Control Model. Journal of Agricultural Safety and Health, 14(1), 79-92.

29. Guest, D.E. (2002). Perspectives on the study of work-life balance. Social Science Information, 41(2), 255-279.

30. Gupta, A. and Sethi, J.A. , (2012). Impact of Quality of Work Life on Employees Perceived Performance, Job Satisfaction and
Employee Commitment. Global Journal of Management and Research, 56-70.

31. Haar, J.M. and Bardoel, E.A. (2008). Positive spill over from the work- family interface: a study of Australian employees. Asia Pacific Journal of Human Resources, 46(3), 275-287.

32. Harris, L.A. and Foster, B. (2008). The drivers of work-life balance: A critical review. [Online]. [Retrieved July 16, 2014], http://www.mngt.waikato.ac.nz/department s/Strategy\%20and\%20Human\%20Resource $\% 20$ Management/airaanz/proceedings/mel bourne2008/ref/L.\%20Harris,\%20B.\%20Fo ster.pdf.

33. Hsieh, Y., Pearson, T., Chang, H. and Uen, J. (2005). Spillover between work and personal life balance for lodging managers. Journal of Human Resources in Hospitality and Tourism, 3(2), 61-83.

34. Hyman, J., Baldry, C., Scholarious, D. and Bunzel, D. (2003). Work-life imbalance in call centres and software development. British Journal of Industrial Relations, 41(2), 215239.

35. Hyman, J., and Summers, J. (2007). Work and life: can employee representation influence balance? Employee Relations, 29(4), 367-384.

36. Jones, F., Burke, R.J. and Westman, M. (2006). Work-life balance: Key issues. In F. Jones, R.J. Burke \& M. Westman (Eds.), Worklife balance: A psychological perspective (pp.138). East Sussex: Psychology Press.

37. Jones, F., Kinman, G. and Payne, N. (2006). Work stress and health behaviours: A work-life balance issue. In F. Jones, R.J. Burke \& M. Westman (Eds.), Work-life balance: A psychological perspective (pp.185-215). East Sussex: Psychology Press.

38. Kinnunen, U. and Mauno, S. (2007). Antecedents and outcomes of work family conflict among employed women and men in Finland. Human Relations, 51(2), 157-177. 
39. Leovaridis, C. (2013). Noi caracteristici ale calității vieții în contextul economiei cunoașterii și al competiției pe plan european. Aspecte organizaționale si manageriale [New characteristics of life quality in the context of knowledge economy and European competition. Organizational and managerial aspects]. Bucharest: Expert Publishing House.

40. Livingston, B.A. (2014). Bargaining Behind the Scenes: Spousal Negotiation, Labor, and Work-Family Burnout. Journal of Management, 40(4), 949-977.

41. Lockwood, N.R. (2003). Work-Life Balance. Challenges and Solutions. [Online]. [Retrieved September 4, 2014], http://www.ispi.org/pdf/suggestedReading/ 11_Lockwood_WorkLifeBalance.pdf.

42. MacInnes, J. (2006). Work-life balance in Europe: A response to the baby bust or reward for the baby boomers?. European Societies, 8(2), 223-249.

43. Macky, K. and Boxall, P.L. (2008). High involvement work processes, work intensification and employee well being: a study of New Zealand worker experiences. Asia Pacific Journal of Human Resources, 46(1), 38-55.

44. Maxwell, G.A. and McDougall, M. (2004). Work-life balance. Public Management Review, 6(3), 377-393.

45. Mayo, M., Pastor, J.C. and Sanz, A.I. (2008). Enabling managers to achieve workfamily balance: A demands- control model of housework behaviour and family satisfaction. IE Business School Working Paper WP08-20. [Online], [Retrieved August 5, 2014], http://ssrn.com/ abstract=1138789.

46. Nordenmark, M., Vinberg, S. and Strandh, M. (2012). Job control and demands, worklife balance and wellbeing among selfemployed men and women in Europe. [Online], [Retrieved September 18, 2014], www.vulnerablegroupsandinclusion.net/ind ex.php/vgi/article/.../24291.
47. Ong, H.L.C. and Jeyaraj, S. (2014). WorkLife Interventions: Differences Between Work-Life Balance and Work-Life Harmony and Its Impact on Creativity at Work. SAGE Open 2014, 4, 1-11.

48. Paille, P., Bourdeau, L. and Galois, I., (2010). Support, trust, satisfaction, intent to leave and citizenship at organizational level a social exchange approach. International Journal of Organizational Analysis, 18(1), 4158.

49. Parker, C.C. (2007). Generational Differences in Work Life Balance Attitudes. A Thesis Submitted to the Department of Psychology of the State University of New York at New Paltz, November 2007.

50. Pedersen, D.E., Minnotte, K., Mannon, S.E. and Kiger, G. (2011). Exploring the relationship between types of family work and marital well-being. Sociological Spectrum, 31, 288-315.

51. Pillinger, J. (2001). Work -Life Balance: Towards a new politics of work and time. Paper given at the Industrial Law Society Annual Conference, 16th September 2001. [Online], [Retrieved July 29, 2014], http://www.industriallawsociety.org.uk/pap ers/pillinger.htm.

52. Powell, G.N. and Greenhaus, J.H. (2006). Managing incidents of work-family conflict: A decision-making perspective. Human Relations, 59(9), 1179-1212.

53. Redmond, J., Valiulis, M. and Drew, E. (2006). Literature review of issues related to work-life balance, workplace culture and maternity/childcare issues. Crisis Pregnancy Agency Report No. 16, June 2006.

54. Shah, S.S. (2014). The Role of WorkFamily Enrichment in Work-Life Balance \& Career Success: A Comparison of German \& Indian Managers. Dissertation Thesis. Faculty of Psychology \& Educational Sciences Ludwig-Maximilians-University, Munich, Germany. 
55. Singh, S. (2013). Work- Life Balance: A Literature Review. Global Journal of Commerce \& Management Perspective, 2(3), 84-91.

56. Sjöberg, L. (2008). Emotional intelligence and life adjustment. In J. C. Cassady \& M. A. Eissa (Eds.), Emotional Intelligence: Perspectives on Educational \& Positive Psychology (pp. 169-184). New York: Peter Lang Publishing.

57. Steiber, N. (2009). Reported levels of time-based and strain-based conflict between work and family roles in Europe: A multilevel approach. Social Indicators Research, 93, 469-488.

58. Stepanova, O. (2012). Work-life balance in organizational subcultures: The case of Mutua. Doctoral Thesis. University of Barcelona, 2012.

59. Thomas, K.J. (2014). Workplace Technology and the Creation of Boundaries: The Role of VHRD in a 24/7 Work Environment. Advances in Developing Human Resources, 16(3), 281-295.
60. Tymon Jr, W.G., Stumpf, S.A. and Simith, R.R. (2011). Manager Support predicts turnover of professionals in India. Career Development International, 16(3), 293-312.

61. Vanishree, P. (2012).Work-Life Balance in the BPO Sector. Journal of Business Management \& Social Sciences Research, 1(2), 35-39.

62. White, M., Hill, S., McGovern, P., Mills, C. and Smeaton, D. (2003). 'High-performance' management practices, working hours and work-life balance. British Journal of Industrial Relations, 41(2), 175-195.

63. Yasbek, P. (2004). The business case for firm-level work-life balance policies: A review of the literature. [Online], [Retrieved August 31 , 2014], www.dol.govt.nz/PDFs/FirmLevelWLB.pdf.

64. Young, M., Schieman, S. and Milkie, M.A. (2014). Spouse's Work-to-family Conflict, Family Stressors, and Mental Health among Dual-earner Mothers and Fathers. Society and Mental Health, 4(1), 1-20. 